\title{
Coastal Impacts, Recovery, and Resilience Post-Hurricane Sandy in the Northeastern US
}

\author{
Amanda L. Babson ${ }^{1}$ (D) $\cdot$ Richard O. Bennett ${ }^{2} \cdot$ Susan Adamowicz ${ }^{3} \cdot$ Sara Stevens $^{4}$ \\ Received: 12 May 2020 / Revised: 10 July 2020 / Accepted: 15 July 2020 / Published online: 25 August 2020 \\ (C) The Author(s) 2020
}

\begin{abstract}
Post-Hurricane Sandy research has improved our understanding of coastal resilience during major storm events, accelerated sea level rise, and other climate-related factors, helping to enhance science-based decision-making, restoration, and management of coastal systems. The central question this special section examines is: "looking across the breadth of research, natural resource management actions and restoration projects post-Hurricane Sandy, what can we say about coastal impact, recovery, and resilience to prepare for increasing impacts of future storms?" These five studies, along with lessons from other published and unpublished research, advance our understanding beyond just the documentation of hurricane impacts but also highlights both natural and managed recovery, thereby advancing the developing field of coastal resilience.
\end{abstract}

Keywords Resilience $\cdot$ Adaptation $\cdot$ Restoration $\cdot$ Hurricane Sandy $\cdot$ Coast $\cdot$ Impact

\section{Introduction}

Hurricane Sandy made landfall as a post-tropical cyclone on October 29, 2012, near Brigantine, New Jersey. Record levels of storm surge were recorded in New Jersey, New York, and Connecticut with tropical storm force winds extending over an area approximately $1600 \mathrm{~km}$ in diameter. The storm affected twenty-four states, with disaster declarations made in 12 States and the District of Columbia. In addition to extensive loss of life and infrastructure damage, there were significant impacts on estuarine and coastal ecosystems throughout the region. The magnitude of Hurricane Sandy and the breadth of research on ecosystem resilience post-Hurricane Sandy provides an opportunity to learn about the response and recovery of coastal ecosystems following the storm and to apply the results to ecosystem management to prepare for future storms.

Communicated by Charles T. Roman

Amanda L. Babson amanda_babson@nps.gov

1 National Park Service, Narragansett, RI, United States

2 U.S. Fish and Wildlife Service, Hadley, MA, USA

3 U.S. Fish and Wildlife Service, Wells, ME, USA

4 National Park Service, Kingston, RI, USA
This perspectives paper sets the context for the special section, which includes studies of post-storm resilience, results of natural resource management actions, and restoration projects as part of the post-Hurricane Sandy coastal resilience efforts by the Department of the Interior (DOI). The section highlights some of the post-Sandy science undertaken to document and understand post-storm ecosystem recovery and resilience, and how systems function, followed by how our management actions can support resilience. The collective research provides an important foundation for managers with data, tools, and information necessary for future natural resource planning and adaptation efforts in preparing for future storms and sea level rise. The five papers in this special section were derived for Hurricane Sandy sessions at the Coastal Estuarine Research Federation Annual Conference (CERF 2017). Although these conference sessions occurred 5 years after Hurricane Sandy and substantial research results had been completed, some restoration projects were just beginning postimplementation monitoring. Some of that monitoring continues today, and we continue to learn from the results. These studies are applicable to other areas impacted by major hurricanes.

The concept of coastal ecosystem resilience has taken a central role in research, yet resilience continues to be challenging to define and measure. Below, we define resilience and explore a range of studies that improve our understanding of how resilience functions in northeastern coastal ecosystems, and how we can expand our management actions to support the resilience of these systems. 


\section{Background}

Resilience is defined differently by different users. One definition of resilience, "the ability to anticipate, prepare for, and adapt to changing conditions and withstand, respond to, and recover rapidly from disruptions," is taken from Executive Order 13653 Preparing the United States for the Impacts of Climate Change (Executive Order 13653, 2013). This was the definition that the goals of the funding supporting a number of these studies aimed to address, yet the different authors in this special section may use variations of the definition. We note that the ecological definition of resilience "the amount of disturbance a system can absorb without changing states" (Holling 1973) is much narrower than the definition used here and that there is active literature (Fisichelli et al. 2016, Stein et al. 2014) on resilience definitions and their role in which adaptation strategies are favored. The authors favor a broader definition because hurricane response efforts are often inclusive of other forms of resilience beyond ecological.

Improving the ecosystem resilience of the United States' northeastern coastline is a massive and multifaceted endeavor. Developing accurate and sensitive performance metrics for detecting and assessing change in resilience is equally complex. In order to track project performance and ultimate contribution to coastal resilience, it is necessary to establish baseline or reference point(s) and a consistent monitoring approach to track changes through time (NAS 2017; NRC 2012; Winderl 2014). As these projects were developed following Hurricane Sandy, adaptation was a relatively new field and the adaptation strategy of increasing resilience was a goal for recovery funding. Whereas there is not a consistent strategy for evaluating resilience here, by exploring different facets, we build a foundation for more systematic evaluations in the future.

As we have been experiencing increased hurricane strength and effects, our understanding of the ecological impacts has been growing. In the Hurricane Sandy-impacted region, fewer than ten hurricanes made landfall between 1899 and 1992, and fewer than five of those were considered major (Neumann et al. 1993). The Gulf of Mexico and Southeast Atlantic Coast have experienced more hurricanes and thus, the research has been more extensive in these regions, with special journal issues on Hurricane Andrew (Pimm et al. 1994), the 1999 hurricane season that included Dennis, Floyd, and Irene (Paerl et al. 2000); the 2004 Florida hurricane season (Greening et al. 2006); and an assessment of social-ecological issues related to hurricanes and other coastal disasters (Adger et al. 2005). The impacts on ecosystems go beyond wind and inundation, with impacts due to salinity changes and loss of dissolved oxygen due to decaying organic matter deposited during the storm. Types of impacts also include oyster mortality (Munroe et al. 2013); mangrove mortality resulting in replacement of black mangrove with red mangrove species or converting to mudflat
(Smith et al. 1994); bird losses including shorebird and wading bird mortality, reduction in resident bird density and nest, and rookery destruction (Roman et al. 1994). The state of the science is moving beyond just documenting changes, but to understanding recovery, and using this scientific basis to better inform management actions.

A greater focus on understanding hurricane impacts, recovery, and resilience is occurring in part because climate change is playing a role in increasing the scale of these impacts. While it is an active research field to better understand the relationship between hurricanes and climate change, and there is low confidence in the detection or attribution of observed trends in hurricane frequency or intensity generally, it is well documented that climate change has contributed to the increases in Atlantic hurricane activity since 1970 and that hurricane rainfall and intensity are projected to increase in the future (IPCC 2014; Hayhoe et al. 2018).

In response to Hurricane Sandy, the United States Congress passed the Hurricane Sandy Disaster Relief Appropriations Act to provide supplemental funding to improve and streamline disaster assistance for Hurricane Sandy impacts. The DOI received approximately $\$ 445$ million, postsequestration, to respond to and recover from Hurricane Sandy impacts. In addition to the more traditional stream of financial support associated with disaster relief, directed towards cleanup and rebuilding based on damages caused by the storm, approximately $\$ 342$ million was appropriated to support resilience. Funds were provided to restore and rebuild national parks, national wildlife refuges, and other Federal public assets with the goal of increasing the resilience and capacity of coastal habitat and infrastructure to withstand and reduce damage from storms (Arkema et al. 2019).

Initially, DOI directed resilience funds to projects that focused on rebuilding infrastructure, or monitoring, mapping, modeling, assessing, and forecasting as identified in the U.S. Geological Survey science plan for support of restoration and recovery in the wake of Hurricane Sandy (Buxton et al. 2013). DOI also conducted a competitive grant process among the DOI Bureaus to fund high priority science, in addition to coastal resilience projects. Subsequently, DOI partnered with the National Fish and Wildlife Foundation (NFWF) to administer the Hurricane Sandy Coastal Resiliency Competitive Grant Program to support approximately $\$ 100$ million in projects led by state and local governments, tribes, nonprofits, and universities. The extent and diversity of competitively funded projects was an opportunity to assess some of the many experimental approaches to increase ecosystem and/or community resilience; they provide the larger context for the synthesis of this paper and this special section highlights but a small fraction of them.

The National Park Service (NPS) initiated multiple scientific studies to assess the response and resilience of coastal park systems following Hurricane Sandy. These projects were 
not only directed at understanding the changes that occurred in parks as a result of the storm but also to develop new science on storm impacts and the natural resiliency of coastal systems. Many of the NPS projects involved enhancing existing longterm monitoring in the parks as part of the NPS Inventory and Monitoring (I\&M) Program (NPS 1992; NPS 2012), as well as creating baseline datasets needed to fulfill gaps in information needed for informed management. The NPS projects took place between 2013 and 2016 and provided a tremendous influx of new information, enhanced existing knowledge for park managers, and provided a better understanding of storm response and recovery that already has been, and continues to be incorporated into park management decisions and planning (NPS 2018).

The U.S. Fish and Wildlife Service (USFWS) resiliency projects that took place across eight national wildlife refuges or refuge complexes focused specifically on restoration and mitigation efforts, unlike the NPS projects, and fell within three primary categories: marsh and beach restoration, improving aquatic connectivity, and living shorelines. Restoration techniques included beneficial use of dredged sediment (thin to thick layer deposition), ditch remediation and runneling, eelgrass bed expansion, and barrier beach/ back barrier ecosystem rebuilding. Aquatic connectivity projects included fish passage and culvert replacement (at two coastal refuges, with inland projects as well). Living shoreline projects included oyster bags, oyster castles, and hybrid measures such as wave attenuation structures across three refuges. Other techniques included invasive species control and removal of transmission poles and associated wires. These management and mitigation focused projects were complemented by scientific studies included in the Stronger Coast Project, which supported salt marsh integrity assessments, shoreline survey and analysis and integrated waterbird management monitoring.

\section{Baseline Science and Monitoring}

Hurricane Sandy provided an important lesson on the value of long-term baseline data and information and the additional need for important datasets. Baseline science collected consistently and following standardized methods over long periods of time are fundamental to understanding and identifying a change in the condition of natural resources and is necessary for informing conservation and land management decisions (Busch and Trexler 2003; Fancy and Bennetts 2012; Vaughan et al. 2001). Both the NPS I\&M Division and the USFWS I\&M Program reliably and consistently collect data throughout the park and national wildlife refuge systems, respectively. These data create the scientific basis for initiating new management practices and changing existing ones in parks and refuges (Fancy et al. 2009) and are critical in helping scientists and managers determine natural levels of variability versus human-induced changes.

One example of how baseline data collected for years prior to the storm improved our understanding of ecosystem resilience was at Fire Island National Seashore where the park experienced dramatic changes during the storm with the development of three breaches along the island (Hapke et al., 2017; van Ormondt et al. 2020). Two of the three breaches were closed immediately after the storm, but a breach that developed in the area of the Otis Pike Fire Island High Dune Wilderness remained open to the Great South Bay due to its wilderness designation. Allowing this breach to remain open created an opportunity for the NPS to study the effects of breaches not only on the island itself but the surrounding Great South Bay (Gobler et al. 2019; Hinrichs et al. 2018, Olin et al. 2019). The long-term monitoring and baseline research collected both before and after the storm supported the extensive environmental impact statement developed to help guide whether the NPS should keep the Fire Island Wilderness breach open or manually close it (NPS 2018). The analysis of both pre-and post-breach data provided a strong scientific basis for allowing the breach to remain open. Other coastal parks and refuges, such as Gateway National Recreation Area, also saw dramatic changes to their shorelines, beaches, dunes, and coastal wetlands, and both the NPS and USFWS had been collecting coastal shoreline change and geomorphological data in these areas for years prior to the storm, creating important pre- and post-storm datasets needed to quantify the recovery of these systems.

The NPS I\&M program was able to collect post-storm data in a timely manner using well-established, standardized methods (Oakley et al. 2003; Perkins et al. 2016; Sergeant et al. 2012). This effort has provided insight into understanding the natural resiliency and recovery of park systems to a powerful storm event like Hurricane Sandy (Wilson et al. 2019).

Despite significant investments in restoration and resilience projects, it is uncommon for funding to be provided to monitor and assess whether projects have met their stated objectives. When funding for monitoring and assessment is available, assessment of ecological outcomes is more common than socio-economic ones (NAS 2017). For the DOI resilience projects, a common set of ecological and socio-economic metrics for evaluating projects was developed after project selection and implementation (DOI 2015; DOI-MEG 2015). As a result, a subset of the projects representing a diversity of geographies, scales, and resilience activities received funding to implement a monitoring effort through 2023. The goal of this monitoring and data collection effort is to collect data for ecological and socio-economic metrics aligned with each of these projects in order to provide a consistent set of data to evaluate the effectiveness of resilience projects to meet their stated objectives. The overarching goals were to (1) reduce the impacts of coastal storm surge, wave velocity, sea level rise, 
and associated natural threats on coastal and inland communities; (2) strengthen the ecological integrity and functionality of coastal/inland ecosystems to protect communities and to enhance fish and wildlife and their associated habitats, and (3) enhance our understanding of the impacts of storm events and identify cost-effective resilience tools that help mitigate the effects of future storms, sea level rise, and other phenomena related to climate change. Metrics were implemented for each of the resilience activities, marsh restoration, living shoreline restoration, beach and/or dune restoration, and restoration of aquatic connectivity. Examples of metrics for marsh restoration include marsh surface elevation or nekton abundance; full tables of ecological metrics by activity are available in DOI (2015). The socio-economic metrics include three categories of metrics: (1) community competence and empowerment, (2) human health and safety, and (3) property and infrastructure protection and enhancement. An example of a human health and safety metric is a reduction in number of households exposed to risk of injury, casualty, or other health effects from a particular flood event with the project as compared to without; full tables of socio-economic metrics by a goal are available in DOI-MEG (2015). The goal is to collect socio-economic data that is aligned with each of the ecological resilience activities, e.g., marsh restoration. The collection of consistent ecological and socio-economic data is intended to determine the ecological and social benefits and the cost-effectiveness of projects.

\section{Sharing Lessons}

Others have evaluated key lessons learned following hurricanes, especially within the disaster response communities including the need for improving communication alerts; finding housing solutions for those displaced; understanding the effect hurricanes have on children's physical health, mental health, and schooling; rebuilding with inclusion; speeding funding and coordination among federal agencies; and embracing resilience as the new planning standard (Atallah and Hoban 2017). It is not so much about hurricane readiness as it is about planning, implementing, and improvising when the disaster does not fit the plan that was developed. An analysis of lessons learned from Hurricane Sandy for the NPS included natural resource recommendations allowing natural processes to prevail; planning for sediment movement; generating monitoring plans; and developing long-term landscape-scale habitat plans (Babson et al. 2016).

As a result of lessons learned from Hurricane Irene in 2011, the Hurricane Sandy Disaster Relief Appropriations Act included amendments to the Stafford Act providing greater flexibility to FEMA for allowing more resilient rebuilding in Sandy-affected areas and in preparation for future storms (Clancy and Grannis 2013). Additionally, the issuance of executive orders and presidential policy directives after Hurricane Sandy helped focus the federal government on disaster resilience - coupling hazard mitigation and recovery efforts to break the damage-repair-damage cycle (GAO 2015).

The Hurricane Sandy Rebuilding Taskforce (2013) recognized the importance of institutionalizing regional approaches for resilience planning and coordination of Hurricane Sandy resilience projects. The DOI Hurricane Sandy program responded to the need for rapid initiation in coastal resilience projects following the devastating coastal impacts of Hurricane Sandy. DOI established a Leadership Team to ensure coordination and communication across Bureaus occurred while providing program oversight and decision-making. Key insights and lessons learned post-implementation of the DOI Hurricane Sandy resilience projects recognize the importance of (1) communicating with the public about each project increased acceptance and at times helped inform project design; (2) designing projects for future conditions (e.g., sea level rise and increased storm intensity) and striving to restore functioning ecosystems and human infrastructure yielded both ecological and economic benefits; (3) possessing prior planning and design studies or identifying projects through a regional planning effort, typically resulted in fewer changes in scope and timeline; (4) establishing baseline conditions, pre- and post-event allowed for better evaluation of management strategies; (5) incorporating a detailed monitoring plan to assess project performance and providing funding to implement the monitoring plan was critical to project assessment; (6) applying ecological and socio-economic metrics was essential to evaluate project effectiveness consistently and was critical to determine best practices for the future; and finally (7) funding should be made available to support data management, analysis, and final report writing (NFWF 2019) in order to complete the cycle of project conception, design, implementation, and assessment.

\section{Science, Outreach, and Communicating with Public}

A major effort to communicate the post-Sandy science to resource managers, affected communities and the broader public helped build partner support and demonstrate the resilience benefits of the projects. Different messaging styles and platforms were used for different projects and audiences.

The NPS supported science communicators who developed project briefs, researcher profiles, videos, StoryMaps, web stories, and a social media campaign. Materials are available at https://www.nps.gov/im/ncbn/briefs-newsletters.htm (accessed June 23, 2020). An analysis of the communication challenges, during both storm preparation and recovery within three parks, includes recommendations to NPS staff and officials, on information availability and access, needed 
protocols and training, and opportunities for teaching moments with the public (Menezes et al. 2019).

The USFWS developed a centralized website with detailed project information and a StoryMap to serve as the spatial platform for basic information as well as the ability to drill down into project specifics (https://www.fws.gov/hurricane/ sandy/index.cfm (accessed June 23, 2020)). From the website, different audiences could access fact sheets, blog posts, videos, and media coverage. Storytelling was effective in showing the benefits to wildlife and people. Benefits of engaging partners early and often were especially evident in large-scale efforts like Prime Hook Wildlife Refuge's beach and salt marsh restoration or the Fire Island Wilderness breach. In considering restoration, resilience, and change, local partners that understand what is happening and why are more accepting of change that is part of adaptation. Going forward, continued communication with communities, demonstrating what worked, can build confidence in investments that utilize forward-thinking science and restoration and have a positive long-term return on investment. Likewise, communicating actions that did not work will provide insight into future decision-making and investments. An Evaluation of the Hurricane Sandy Resilience Program (NFWF 2019) found that projects improved ecological and human community resilience, filled key knowledge gaps, provided direct benefits, and catalyzed planning for future activities.

\section{Overview of Papers in Special Section}

The five papers included in this special section provide examples of multiple issues related to storm impacts, recovery, and resilience. Kang and Xia (2020) model circulation and a storm surge of the Maryland Coastal Bays: the interactions between winds, surge, and high river flow during the storm. Understanding the role of different drivers of flooding and hydrodynamic exchange on an event scale is transferable to other shallow estuaries and lagoons, especially those with multiple inlets. Yeates et al. (2020) provide a regional-scale analysis of the storm's role in salt marsh surface elevation. Morris et al. (2020) model salt marsh change for four parks with differing sediment budgets, but more importantly, differing organic matter production. Burdick et al. (2019) provide an evaluation of a management tool, ditch remediation, one of a range of restoration techniques tested post-Hurricane Sandy, with the idea that restored salt marshes can better trap sediment and increase organic matter production, thus will be more resilient. Olin et al. (2019) explore the response of the Great South Bay, NY, following the breach of Fire Island, studying nekton and community assemblages.

Olin et al. (2019), along with many other studies, including Hinrichs et al. (2018) and Gobler et al. (2019), informed the Environmental Impact Statement recommendations (NPS
2018) for the Fire Island Wilderness breach. As other barrier islands breach in future storms, having the experience of monitoring the water quality, geomorphic response, and ecosystem benefits documented by allowing the Fire Island breach to remain open may help shape future decision-making, as well as monitoring plans. The demonstration of geomorphic resilience at Fire Island, NY, which is modeled by Wilson et al. (2019), is further explored by Psuty et al. (2020), documenting dune displacement and recovery at Fort Tilden, Gateway National Recreation Area, NY, including interactions with groins and bulkheads that disrupt sediment transport.

Given the variety of post-Sandy management actions to support resilience that relies on changes in marsh sediment budgets and distribution (e.g., ditch filling, thin layer deposition, removing tidal restrictions), Ganju (2019) makes the case for including sediment budgets in restoration planning, especially for salt marshes.

Other reports share results from broader Hurricane Sandy resilience projects, including Tinoco and Peterson (2016), that evaluate the effect of the Fire Island Wilderness breach on seagrasses. Several studies conducted at National Seashores along the mid-Atlantic coast conducted groundwater modeling to evaluate the effects of climate change on barrier island groundwater dynamics (Carleton et al. 2020; Fleming et al. in press; Misut and Dressler in press).

The collective post-Hurricane Sandy research presented in this special section, along with other post-Sandy research, advances our understanding of natural resiliency, as well as, the efficacy of building resilience through restoration and management applications.

Acknowledgments The authors would like to thank David Eisenhauer and Norbert Psuty for contributions to the manuscript and the National Wildlife Refuges and National Parks that hosted the projects. The paper was much improved thanks to peer review comments from Charles Roman and an anonymous reviewer.

\section{Compliance with Ethical Standards}

Disclaimer The findings and conclusions in this article are those of the author(s) and do not necessarily represent the views of the U.S. Fish and Wildlife Service or the National Park Service.

Open Access This article is licensed under a Creative Commons Attribution 4.0 International License, which permits use, sharing, adaptation, distribution and reproduction in any medium or format, as long as you give appropriate credit to the original author(s) and the source, provide a link to the Creative Commons licence, and indicate if changes were made. The images or other third party material in this article are included in the article's Creative Commons licence, unless indicated otherwise in a credit line to the material. If material is not included in the article's Creative Commons licence and your intended use is not permitted by statutory regulation or exceeds the permitted use, you will need to obtain permission directly from the copyright holder. To view a copy of this licence, visit http://creativecommons.org/licenses/by/4.0/. 


\section{References}

Adger, W.N., T.P. Hughes, C. Folke, S.R. Carpenter, and J. Rockström. 2005. Social-ecological resilience to coastal disasters. Science 309 (5737): 1036-1039.

Arkema, K., R. Bennett, A. Dausman, and L. Materman. 2019. Chapter 14. United States: Blending finance mechanisms for coastal resilience and climate adaptation. In Natural capital policy and $f i-$ nance mechanisms around the world - Green growth that works, ed. L. Mandle, Z. Ouyang, J. Salzman, and G. Daily, 213-236. Washington, DC: Island Press.

Atallah, N., and B. Hoban. 2017. Some lessons to learn after hurricanes, Brookings Now, September, 2017, 3 pp. https://www.brookings. edu/blog/brookings-now/2017/09/12/some-lessons-to-learn-afterhurricanes/. Accessed 26 June 2020.

Babson, A.L., R. Beavers, M. Eissenberg, M. Foley, T. Hudson, and C. Schupp. 2016. Lessons learned from Hurricane Sandy. In Coastal adaptation strategies handbook, ed. R. Beavers, A. Babson, and C. Schupp. Washington, DC: National Park Service.

Burdick, D. M., G. E. Moore, S. C. Adamowicz, G. M. Wilson, and C. R. Peter. (2019). Mitigating the legacy effects of ditching in a New England salt marsh. Estuaries and Coasts. https://doi.org/10.1007/ s12237-019-00656-5. Accessed 26 June 2020.

Busch, E.D., and J.C. Trexler. 2003. The importance of monitoring in regional ecosystem initiatives. In Monitoring ecosystems: Interdisciplinary approaches for evaluating ecoregional initiatives, ed. E.D. Busch and J.C. Trexler, 1-23. Washington, DC: Island Press.

Buxton, H. T., M. E. Andersen, M. J. Focazio, J. W. Haines, R. A. Hainly, D. J. Hippe, and L. J. Sugarbaker. 2013. Meeting the science needs of the Nation in the wake of Hurricane Sandy-A U.S. Geological Survey science plan for support of restoration and recovery: U.S. Geological Survey Circular 1390, 26 p. https://pubs.usgs.gov/circ/ 1390/circ1390.pdf. Accessed 26 June 2020

Carleton, G. B., E. G. Charles, A. R. Fiore, and R. B. Winston. (2020). Simulation of water-table response to climate-change-driven sealevel rise and change in recharge, Sandy Hook Unit, Gateway National Recreation Area, New Jersey: U.S. Geological Survey Scientific Investigations Report 2020-5080.

Clancy, J. B., and J. Grannis. 2013. Lessons learned from Irene, climate change, federal disaster relief, and barriers to adaptive reconstruction. Georgetown Climate Center, December, 2013, 17 pp. https:// www.georgetownclimate.org/files/report/Lessons\%20Learned\% 20From\%20Irene\%20-\%20Finalv2.pdf. Accessed 26 June 2020.

Department of Interior (DOI). 2015. Developing socio-economic metrics to measure DOI Hurricane Sandy project and program outcomes, $120 \mathrm{pp}$. https://www.doi.gov/sites/doi.gov/files/uploads/ Socio_Economic_Metrics_Final_Report_11DEC2015_0.pdf. Accessed 26 June 2020

Department of the Interior - Metrics Expert Group (DOI-MEG). 2015. Report for the Department of the Interior, Recommendations for assessing the effects of the DOI Hurricane Sandy Mitigation and Resilience Program on ecological system and infrastructure resilience in the Northeast coastal region,64 p.https://www.doi.gov/ sites/doi.gov/files/migrated/news/upload/Hurricane-Sandy-projectmetrics-report.pdf. Accessed 26 June 2020.

Executive Order (EO) 13653, "Preparing the United States for the Impacts of Climate Change." 78 FR 66819. 6 November 2013. http://www.gpo.gov/fdsys/pkg/FR-2013-11-06/pdf/201326785.pdf. Accessed 26 June 2020.

Fancy, S.G., and R.E. Bennetts. 2012. Institutionalizing an effective longterm monitoring program in the US National Park Service. In Design and analysis of long-term ecological monitoring studies, ed. Gitzen et al., 481-497. Cambridge: Cambridge University Press.
Fancy, S.G., J.E. Gross, and S.L. Carter. 2009. Monitoring the condition of natural resources in US national parks. Environmental Monitoring and Assessment 151 (1-4): 161-174.

Fisichelli, N., G.W. Schuurman, and C. Hawkins Hoffman. 2016. Is 'resilience' maladaptive? Towards an accurate Lexicon for climate change adaptation. Environmental Management 57 (4): 753-758.

Fleming, B. J., J. P. Raffensperger, P. J. Goodling, and J. P. Masterson. (in press). Simulated effects of sea-level rise on the shallow, fresh groundwater system of Assateague Island, Maryland and Virginia: U.S. Geological Survey Scientific Investigations Report.

Ganju, N.K. 2019. Marshes are the new beaches: Integrating sediment transport into restoration planning. Estuaries and Coasts 42 (4): 917-926. https://doi.org/10.1007/s12237-019-00531-3. Accessed 26 June 2020.

Government Accountability Office (GAO). 2015. Hurricane Sandy - an investment strategy could help the federal government enhance national resilience for future disasters, GAO-15-515, July 2015, 93 pp.https://www.gao.gov/assets/680/671796.pdf. Accessed 26 June 2020 .

Gobler, C. J., C. S. Young, , J. Goleski, A. Stevens, J. Thickman, R. B. Wallace, and T. K. Hattenrath-Lehmann. 2019. Accidental ecosystem restoration? Assessing the estuary-wide impacts of a new ocean inlet created by Hurricane Sandy. Estuarine, Coastal and Shelf Science 222(31):132-146.

Greening, H., P. Doering, and C. Corbett. 2006. Hurricane impacts on coastal ecosystems. Estuaries and Coasts 29 (6a): 877-879.

Hayhoe, K., D.J. Wuebbles, D.R. Easterling, D.W. Fahey, S. Doherty, J. Kossin, W. Sweet, R. Vose, and M. Wehner. 2018. Our changing climate. In Impacts, risks, and adaptation in the United States: Fourth National Climate Assessment, ed. D.R. Reidmiller, C.W. Avery, D.R. Easterling, K.E. Kunkel, K.L.M. Lewis, T.K. Maycock, and B.C. Stewart, vol. II, 72-144. Washington, DC: U.S. Global Change Research Program. https://doi.org/10.7930/ NCA4.2018.CH2.

Hinrichs, C., C.N. Flagg, and R.E. Wilson. 2018. Great South Bay after Sandy: Changes in circulation and flushing due to new inlet. Estuaries and Coasts 41 (8): 2172-2190.

Holling, C.S. 1973. Resilience and stability of ecological systems. Annual Review of Ecology and Systematics 4 (1): 1-23.

Hurricane Sandy Rebuilding Taskforce. 2013. The Hurricane Sandy rebuilding strategy, stronger communities, a resilient region. Washington, DC, 208 pp. https://www.hud.gov/sites/documents/ HSREBUILDINGSTRATEGY.PDF. Accessed 26 June 2020.

Intergovernmental Panel on Climate Change (IPCC). 2014. Summary for policymakers. In Climate change 2014: Impacts, adaptation, and vulnerability, Part A: Global and sectoral aspects, eds. C. B. Field, V. R. Barros, K. J. Mach, et al. Contribution of working group II to the fifth assessment report of the intergovernmental panel.

Kang, X., and M. Xia. 2020. The study of the hurricane-induced storm surge and bay-ocean exchange using a nesting model. Estuaries and Coasts. https://doi.org/10.1007/s12237-020-00695-3. Accessed 26 June 2020

Menezes, S., K. Southern, K. McDuffie, and M. Birk. 2019. Improving National Park Service communication before and after natural disasters: Lessons learned from Hurricane Sandy planning and response. Natural Resource Report NPS/NCBN/NRR—2019/1935. National Park Service, Fort Collins, Colorado.

Misut, P. E., and S. Dressler. (in press). Simulation of water-table and freshwater/saltwater interface response to climate-change-driven sealevel rise and changes in recharge, Fire Island National Seashore, New York: U.S. Geological Survey Scientific Investigations Report.

Morris, J. T., J. Lynch, K. A. Renken, S. Stevens, M. Tyrrell, and H. Plaisted. 2020. Tidal and hurricane impacts on saltmarshes in the Northeastern Coastal and Barrier Network: theory and empirical results. Estuaries and Coasts. https://doi.org/10.1007/s12237-02000790-5. 
Munroe, D., A. Tabatabai, I. Burt, D. Bushek, E.N. Powell, and J. Wilkin. 2013. Oyster mortality in Delaware Bay: Impacts and recovery from Hurricane Irene and Tropical Storm Lee. Estuarine, Coastal and Shelf Science 135: 209-219.

National Academies of Sciences, Engineering, and Medicine (NAS). 2017. Effective monitoring to evaluate ecological restoration in the Gulf of Mexico. Washington, DC: The National Academies Press, 219 pp. https://doi.org/10.17226/23476. Accessed 26 June 2020.

Neumann, C. J., National Climatic Data Center (U.S.), National Hurricane Center (1965-1995), National Weather Service, National Environmental Satellite, Data, and Information Service. Asheville, N.C. : U.S. Department of Commerce, National Oceanic and Atmospheric Administration, National Weather Service, National Environmental Satellite, Data, and Information Service. 1993. Tropical cyclones of the North Atlantic Ocean, 1871-1992. 193 pp.

NFWF. 2019. Evaluation of Hurricane Sandy Coastal Resilience Program. Final Report, Prepared for the National Fish and Wildlife Foundation and Department of the Interior, Abt Associates, Rockville, MD, 93 pp. https://live-nfwf-2019.pantheonsite.io/sites/ default/files/hurricanesandy/Documents/hurricane-sandyevaluation-final-report.pdf

National Park Service (NPS). 1992. Natural Resources Inventory and Monitoring guideline. NPS-75. National Park Service, Natural Resource Stewardship and Science. Washington, DC.

National Park Service (NPS). 2012. Guidance for designing an integrated monitoring program. Natural Resource Report NPS/NRSS/NRR545. National Park Service, Fort Collins.

National Park Service (NPS). 2018. Fire Island National Seashore: Fire Island Wilderness Breach Management Plan/Environmental Impact Statement. https://parkplanning.nps.gov/projectHome.cfm? projectId $=58824$

National Park Service (NPS). "Inventory and Monitoring Division (U.S. National Park Service).” National Park Service: Inventory and Monitoring, U.S. Department of the Interior, www.nps.gov/im/ index.htm, Accessed 29 March 2019.

National Research Council (NRC). 2012. Disaster resilience: A national imperative. Washington, DC: The National Academies Press, 260 pp. https://doi.org/10.17226/13457. Accessed 26 June 2020.

Oakley, K.L., L.P. Thomas, and S.G. Fancy. 2003. Guidelines for longterm monitoring protocols. Wildlife Society Bulletin 31: 1000-1003.

Olin, J. A., R. M. Cerrato, J. A. Nye, S. R. Sagarese, M. Sclafani, J. P. Zacharias, and M. G. Frisk. 2019. Evidence for ecosystem changes within a temperate lagoon following a hurricane-induced barrier island breach. Estuaries and Coasts. https://doi.org/10.1007/ s12237-019-00593-3. Accessed 26 June 2020.

Paerl, H.W., J.D. Bales, L.W. Ausley, C.P. Buzzelli, L.B. Crowder, L.A. Eby, M. Go, B.L. Peierls, T.L. Richardson, and J.S. Ramus. 2000. Hurricanes' hydrological, ecological effects linger in major U.S. estuary. EOS 81 (40): 457-462.

Perkins, D. W., M. Bozek, M. MacCluskie, T. Philippi, A. Ray, W. Route, and D. Thoma. 2016. Excellent science in the National Park Service Inventory and Monitoring Division: Guiding principles and recommendations. Natural Resource Report NPS/WASO/ NRR -2016/1217. National Park Service, Fort Collins, Colorado.

Pimm, S.L., G.E. Davis, L. Loope, C.T. Roman, T.J. Smith III., and J.T. Tilmant. 1994. Hurricane Andrew: The 1992 hurricane allowed scientists to assess damage and consider long-term consequences to well-studied ecosystems. BioScience 44 (4): 224-229. https://doi. org/10.2307/1312226 (Accessed 26 June 2020).

Psuty, N. P.; K. Ames; G. Liu, and A. Habeck. 2020. Interactive geomorphological resilience of sediment pathways and coastal features, post-Hurricane Sandy, Fort Tilden, New York. Journal of Coastal Research. Coconut Creek, Florida. https://doi.org/10.2112/ JCOASTRES-D-19-00126.1. Accessed 26 June 2020.

Roman, C.T., N.G. Aumen, J.C. Trexler, R.J. Fennema, W.F. Loftus, and M.A. Soukup. 1994. Hurricane Andrew's impact on freshwater resources: Water quality, so important to defining the Everglades' unique ecological composition, appears little affected. BioScience 44 (4): 247-255. https://doi.org/10.2307/1312229 Accessed 26 June 2020.

Sergeant, C.J., B.J. Moynahan, and W.F. Johnson. 2012. Practical advice for implementing long-term ecosystem monitoring. Journal of Applied Ecology 49 (5): 969-973.

Smith, T.J., M.B. Robblee, H.R. Wanless, and T.W. Doyle. 1994. Mangroves, hurricanes, and lightning strikes: Assessment of Hurricane Andrew suggests an interaction across two differing scales of disturbance. BioScience 44 (4): 256-262.

Stein, B.A., P. Glick, N. Edelson, and A. Staudt, eds. 2014. Climatesmart conservation: Putting adaptation principles into practice. Washington, D.C.: National Wildlife Federation.

Tinoco, A.I. and B. J. Peterson. 2016. Effects of Hurricane Sandy on Fire Island National Seashore (NY): Assessing seagrass-associated nekton communities (July 2018 update). Natural Resource Report. NPS/NCBN/NRR - 2018/1683. National Park Service. Fort Collins, Colorado.

Vaughan, H., T. Brydges, A. Fenech, and A. Lumb. 2001. Monitoring long-term ecological changes through the Ecological Monitoring and Assessment Network: Science based and policy relevant. Environmental Monitoring and Assessment 67 (1/2): 3-28.

Wilson, K., E. Lentz, J.L. Miselis, I. Safak, and B.T. Owen. 2019. A Bayesian approach to predict sub-annual beach change and recovery. Estuaries and Coasts 42 (1): 112-131.

Winderl, T. 2014. United Nations Development Programme, Disaster Resilience Measurements - Stocktaking of Ongoing Efforts in Developing Systems for Measuring Resilience, 59 pp., https:// floodresilience.net/resources/item/disaster-resilience-measurements-stocktaking-of-ongoing-efforts-in-developing-systems-formeasuring-resilience

Yeates, A.G., J. B. Grace, J. H. Olker, G. G. Guntenspergen, D. R. Cahoon, S. Adamowicz, S. C. Anisfeld, N. Barrett, A. Benzecry, L. Blum, R. R. Christian, J. Grzyb, E. Kracauer Hartig, K. Hines Leo, S. Lerberg, J. C. Lynch, N. Maher, J. P. Megonigal, W. Reay, D. Siok, A. Starke, V. Turner, and S. Warren. 2020. Hurricane Sandy effects on coastal marsh elevation change. Estuaries and Coasts. https://doi.org/10.1007/s12237-020-00758-5. Accessed 10 July 2020. 